\title{
Synthesis and Comparative Characterization of Different Microparticles used as Biomaterials in Dentistry
}

\author{
SERGIU ALEXANDRU TOFAN ${ }^{1 \#, ~ C R I S T I A N ~ O L T E A N U ~}{ }^{2 \#}$, CAMELIA SZUHANEK ${ }^{3,4 \#,}$ \\ RAMONA AMINA POPOVICI ${ }^{1}$, MAGDA MIHAELA LUCA ${ }^{3,5^{*}}$, ANDRADA IFTODE, \\ IOANA ZINUCA PAVEL ${ }^{6,7 *}$, DAN FLORIN BONTA ${ }^{8}$ \\ 1 "Victor Babes" University of Medicine and Pharmacy, Faculty of Dentistry, Department 1, 2 Eftimie Murgu Sq., 300041 \\ Timisoara, Romania \\ 2 "Iuliu Hatieganu" University of Medicine and Pharmacy, Faculty of Dentistry, Department of Orthodontics, 4 Louis Pasteur \\ Str., 400349, Cluj-Napoca, Romania \\ 3 "Victor Babes" University of Medicine and Pharmacy, Faculty of Dentistry, Department 2, 2 Eftimie Murgu Sq., 300041 \\ Timisoara, Romania \\ 4"Victor Babes" University of Medicine and Pharmacy, Orthodontic Research Center (ORTHO-CENTER), 2 Eftimie Murgu \\ Sq., 300041 Timisoara, Romania \\ 5 "Victor Babes" University of Medicine and Pharmacy, Pediatric Dentistry Research Center (PDRC), 2 Eftimie Murgu Sq., \\ 300041 Timisoara, Romania \\ 6 "Victor Babes" University of Medicine and Pharmacy, Faculty of Pharmacy, Department 2, 2 Eftimie Murgu Sq., 300041 \\ Timisoara, Romania \\ 7 "Victor Babes" University of Medicine and Pharmacy, Research Centre for Pharmaco-Toxicological Evaluation, 2 Eftimie \\ Murgu Sq., 300041, Timisoara, Romania \\ ${ }^{8}$ University of Oradea, Faculty of Medicine and Pharmacy, Department of Dental Medicine, 101 Decembrie Sq., 410068, \\ Oradea, Romania
}

Abstract: A biomaterial must be biologically compatible, mechanical, functional, corrosion resistant and easily adapt to clinical and laboratory technologies. Dental biomaterials are materials used to replace a part of a living system or to work closely with living tissue. Many scientific articles present different polymeric biocomposites with possible application in dentistry and this is a proof of the opportunity of a research in a field in full ascent and with great availability in the promotion of materials destined to "work under biological constraint" and which must also meet the functional requirements of a dental implant. The objectives of this research were to obtain and to comparatively evaluate different polymeric microparticles that can be used in dentistry. The samples based on poly(lactic-coglycolic acid) and respectively polyurethane microparticles were characterized by $\mathrm{pH}$ and Zetasizer measurements, and in vitro cytotoxicity assays. The results indicate the obtaining of particles with a neutral $\mathrm{pH}$, medium homogeneity, and with different tendencies to form agglomerations. Their low cytotoxicity, tested on the primary human gingival fibroblasts by MTT and LDH techniques, indicates that these microparticles are safe to be tested in further clinical evaluations.

Keywords: PLGA, polyurethane, Zetasizer, HGF primary gingival fibroblast, cytotoxicity

\section{Introduction}

The research in the field of materials science and engineering has expanded greatly in recent decades, especially in the field of biocompatible materials, known as biomaterials. Two main reasons lead to this progress: on the one hand, medicine is constantly looking for solutions to remedy many health problems, and on the other hand, certain classes of materials have already proven useful in ameliorating or even curing certain human suffering. David F. Williams, a professor at the University of Liverpool, defines biomaterials as a substance or a mixture of substances, obtained naturally or via synthetic techniques. He indicated that the biomaterials can be used entirely or as a component part of a system that can be used to treat or to replace a tissue, an organ or a function of the body for a specified period of time $[1,2]$. 
The performance of the field and the condition of success in oral implantology requires today the revision and the re-evaluation of the means that essentially contribute to ensuring the stability and durability of the implant, starting from the nature of the biomaterial and continuing with the characteristics of the optimally designed biosurfaces. The dynamics of development and the advances in oral implantology cannot be separated from the dynamics of research development in materials science and engineering and the capitalization of top results of teams of researchers in interdisciplinary fields such as chemistry, biology, engineering and dentistry. Current research on the modification and control of the biomaterial-tissue interaction for improving the process of osseointegration of the implant are oriented towards capitalizing on the progress made in regenerative medicine, using tissue engineering techniques and developing the field of biomimetic materials (so-called intelligent biomaterials) [3].

The most commonly used synthetic biomaterials are: (1) metallics or alloys (good electrical and thermal conductivity, mechanical strength and high rigidity; they are used in orthopedics, oral and maxillofacial surgery; (2) polymeric (poor electrical, thermal conductivity and mechanical resistance, are very ductile and resistant to shocks; they are used as hydrogels, for contact lenses, hemodialysis membranes, vocal cord replacements, artificial skin, tendons, etc.); (3) ceramics (high resistance to mass, rigidity and fire resistance, corrosion resistance; they are used in dentistry, ophthalmology, orthopedics etc.) [4].

The polymeric biomaterials based on polyethylene, polyvinyl, polyesters, PTFE and silicon rubber are used in cardiovascular implants, while polyethylene, polymethyl and polymethacrylates are often found in orthopedics implants and polylactic and/or polyglycolic acids are used in the synthesis of artificial tissues. Nowadays, different combinations and co-polymers are developed to obtain novel materials with enhanced properties.

The use of polymeric materials has increased in dentistry, not only due to their excellent surfaces, but also due to the excellent mechanical and biological properties, as well as the low cost of production and ease of processing.

Polymers are macromolecules with high molecular weight, resulting from the repetition of structural units from the respective monomers. The most commonly used polymers in dentistry are: polymethyl methacrylate (PMMA) [- $\left.\left\{\mathrm{CH}_{2}-\mathrm{C}\left(\mathrm{CH}_{3}\right)-\mathrm{CO}-\mathrm{OCH}_{3}\right\}-\right]$, polyethylene (PE) [-( $\left.\left.\mathrm{CH}_{2}-\mathrm{CH}_{2}\right)-\right]$, polyethylene glycol (PEG) $\left[-\left\{\mathrm{CH}_{3}(\mathrm{O})-\mathrm{CH}_{3}(\mathrm{O})\right\}-\right]$, polycarbonate $(\mathrm{PC})[-\{\mathrm{O}-(\mathrm{CO})-\mathrm{O}\}-]$, polylactic acid (PLLA) $\left[-\left\{\mathrm{O}-\mathrm{CH}\left(\mathrm{CH}_{3}\right)-\mathrm{O}\right\}-\right]$, polydimethylsiloxane $\left[-\left\{\left(\mathrm{CH}_{3}\right)_{2}-\mathrm{Si}-\mathrm{O}\right\}-\right]$, polyurethane (PUR) [-(NH-COO)-], poly(e-caprolactone) (PCL) $\left[-\left\{\mathrm{CO}\left(\mathrm{CH}_{2}\right)_{5}-\mathrm{O}\right\}-\right]$, polypyrrole (PPy) $\left[-\left\{\mathrm{CH}_{4} \mathrm{H}_{5}-\mathrm{N}\right\}-\right]$, hexamethyldisilazane (HMDC) $\left[-\left\{\mathrm{C}_{6} \mathrm{H}_{19}-\mathrm{N}_{5}-\mathrm{Si}_{2}\right\}-\right]$, N-tert-butylacrylamide $\left.\left[-\left\{\mathrm{C}_{7} \mathrm{H}_{13}-\mathrm{NO}\right)\right\}-\right]$, Nisopropylacrylamide $\left.\left[-\left\{\mathrm{C}_{6} \mathrm{H}_{11}-\mathrm{NO}\right)\right\}-\right]$, hydrogel $\left.\left[-\left\{\mathrm{C}_{3} \mathrm{H}_{3}-\mathrm{NaO}_{2}\right)\right\}-\right][5]$.

The main aims of this research were the study of polymeric biomaterials and the evaluation of their biocompatibility on primary human gingival fibroblasts - HGF cells, in terms of cell viability and cytotoxicity.

\section{Materials and methods}

\subsection{The reagents}

The following substances were used in this study: ethylene glycol (EG) purchased from Lach-Ner s.r.o. (Czech Republic), 1,4-butanediol (BD) obtained from Carl Roth GmbH (Germany), polyethylene glycol M200 (PEG), acetone, $\operatorname{Span}^{\circledR} 85$, and hexamethylene-diisocyanate (HMDI) acquired from Merck (Germany). D, L lactic acid and glycolic acid were obtained from Fluka. All reagents were kept under the conditions that were mentioned by the suppliers and they were not purified before the synthesis.

\subsection{The synthesis procedure}

The synthesis of poly(lactic-co-glycolic acid) (PLGA) particles was already described in the literature [6]. A proper amount of polymer was dissolved in acetone and the mixture was then emulsified in a large quantity of water with surfactant $\left(\mathrm{Span}^{\circledR} 85\right)$ at $55^{\circ} \mathrm{C}$ and under vigorous stirring (550 rpm). In the next step, acetone was evaporated at atmospheric pressure with controlling the stirring rate as solvent 
evaporates; the emulsion was transferred in another flask with distilled water without surfactant. Finally, the PLGA microparticles were repeatedly washed and dried. The equation of the chemical reaction is presented in Figure 1.

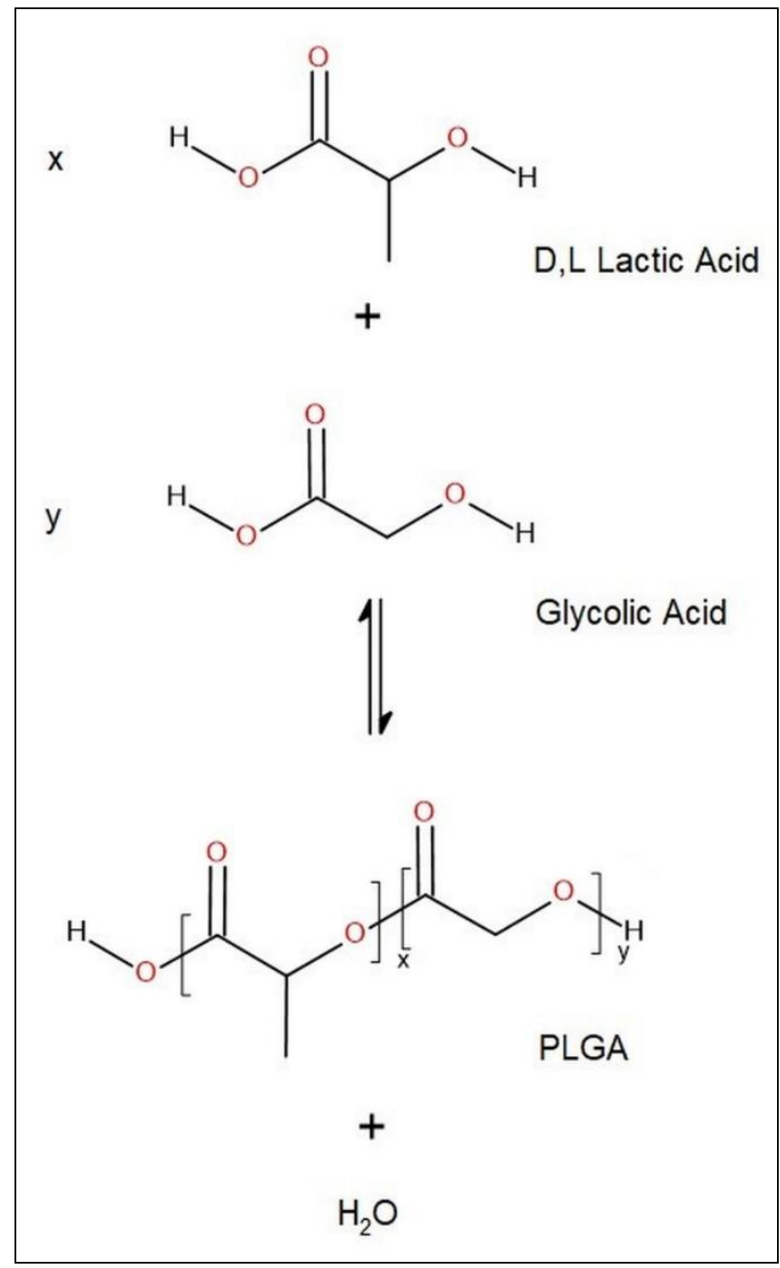

Figure 1. The chemical synthesis of PLGA

Another protocol was used to synthesize hollow polyurethane (PU) microparticles [7], slightly modified:

- an organic component based on a solution containing 5.0 mL HMDI in $50 \mathrm{~mL}$ acetone was homogenized under magnetic stirring $(400 \mathrm{rpm})$ at $25^{\circ} \mathrm{C}$ for $10 \mathrm{~min}$;

- a hydroxylic component based on a mixture of $1.6 \mathrm{~mL}$ EG, $1.4 \mathrm{~mL} \mathrm{BD}, 2.0 \mathrm{~mL}$ PEG, and $1.5 \mathrm{~mL}$ Span ${ }^{\circledR} 85$ in $50 \mathrm{~mL}$ distilled water was homogenized in the same conditions;

- the components were then mixed together $(350 \mathrm{rpm})$ at $30^{\circ} \mathrm{C}$ for $3.5 \mathrm{~h}$ due to the absence of any catalyst;

- the obtained products were repeatedly washed and centrifuged and they were dried as thin layers in Petri dishes at $65^{\circ} \mathrm{C}$ for almost $48 \mathrm{~h}$.

\subsection{Evaluation of the samples}

The $p \mathrm{H}$ of the aqueous solutions (1:50, w/v) of the two polymeric biomaterials was measured with a $\mathrm{pH}$ Meter Checker ${ }^{\circledR}$ from Hanna Instruments (USA) at the same temperature $\left(20^{\circ} \mathrm{C}\right)$. Commercial buffer solutions, PH ROTI Calipure $(p \mathrm{H}=4.0,7.0$, and respectively 10.0), were previously used for the calibration of the instrument.

The Zetasizer procedure was involved to evaluate the size and the potential to form agglomerates of the samples by means of a Wallis Zeta potential Analyzer and a Vasco Particle Size Analyzer, both 
devices purchased from Cordouan Technology (France); the following input parameters were set for these analyses: assessment temperature $\left(25 \pm 1^{\circ} \mathrm{C}\right)$, interval of time $(30 \pm 3 \mu \mathrm{s})$, number of channels (around 400), power of laser (90\%), acquisition mode (continuous), analysis mode (Pade-Laplace), Wallis resolution (medium), and Smoluchowski model as Henry function.

In vitro evaluation of the samples has been done by direct exposure to primary human gingival fibroblasts (HGF). The protocol consisted in maintaining small amounts of every sample $(0.01 \mathrm{~g})$ in cell culture medium at $37^{\circ} \mathrm{C}$ for a period of $24 \mathrm{~h}$. In order to mimic the physiological conditions of the oral cavity and the salivary flow, intermittent shaking was used throughout the 24h period [8]. The International Standard Organization (ISO standard 10993-5:2009) approves this protocol for the evaluation of the cytotoxic effect [9]. The above mentioned cell culture medium was further used for stimulation of the HGF cells in order to find a possible cytotoxic effect.

HGF cells were purchased from the American Type Culture Collection (ATCC ${ }^{\circledR}$ PCS-201-018 ${ }^{\mathrm{TM}}$ ). The cells were cultured in Fibroblast Basal Medium supplemented with Fibroblast Growth Kit-Low serum. In order to avoid contamination, a mixture of $0.1 \%$ Penicillin-Streptomycin-Amphotericin B Solution was added to the medium. The cells were kept under standard conditions: at $37^{\circ} \mathrm{C}$ and a humidified atmosphere $\left(5 \% \mathrm{CO}_{2}\right)$ in a Steri-Cycle i160 incubator (Thermo Fisher Scientific, USA).

In order to determine the effect of the samples on HGF cells viability, a MTT (3-(4,5dimethylthiazol-2-yl)-2,5-diphenyltetrazolium bromide) assay was performed. The technique consisted in evaluating the activity of mitochondrial dehydrogenase from metabolically viable cells. The MTT was reduced by active cells to formazan and further the absorbance was spectrophotometrically measured at $570 \mathrm{~nm}$, according to one of our previous studies [10].

For the evaluation of the cytotoxic effect of the samples on HGF cells, lactate dehydrogenase (LDH) assay was performed. The technique consisted in evaluating the released cytosolic enzyme LDH into the extracellular medium, an effect that occurs when the cellular membrane is damaged. The method is similar with MTT assay, with some exceptions [11]. The amount of LDH released into the medium was evaluated using a microplate reader $\mathrm{xMark}^{\mathrm{TM}}$ Microplate from Bio-Rad Laboratories (USA); the absorbance was spectrophotometrically measured at 490 and $680 \mathrm{~nm}$.

IBM SPSS v.23 was used for the statistical analysis of the data. All results were expressed as average values \pm SE. One-way analysis of variance (ANOVA) followed by Bonferroni multiple comparisons test were applied. $*$ for $\mathrm{p}<0.05$, $* *$ for $\mathrm{p}<0.01$, and $* * *$ for $\mathrm{p}<0.001$ were used. The data processing was reviewed by an independent statistician.

\section{Results and discussions}

\subsection{The evaluations of $p H$}

S. Baliga et al. [12] have reported that salivary $p \mathrm{H}$, a possible diagnostic biomarker, is between 6.2 and 7.6 with 6.7 as the average value. The $p \mathrm{H}$ values of the present formulations were satisfactory: 6.65 (PLGA sample) and respectively 6.83 (polyurethane particles).

\subsection{Zetasizer characterization}

Table 1 presents the Zetasizer characteristics of the synthesized microparticles. These values indicate the obtaining of polymeric microparticles with the mean sizes between 160 and $200 \mathrm{~nm}$, described by a medium homogeneity (the polydispersity index, PDI is 0.5 ) and with different tendency to form agglomerations according to Gallardo et al. [13]: PU biomaterial present a medium stability while the PLGA is stable (Zeta potential is more than $+30 \mathrm{mV}$ ).

Table 1. The Zetasizer characteristics of samples.

\begin{tabular}{|c|c|c|c|}
\hline \multirow{2}{*}{ Sample } & \multicolumn{2}{|c|}{ Size of structures $(\mathbf{n m})$} & \multirow{2}{*}{ Zeta potential $(\mathbf{m V})$} \\
\cline { 2 - 4 } & Mean \pm SD & PDI & +32.14 \\
\hline PLGA & $192 \pm 8$ & 0.5 & +25.35 \\
\hline PU & $161 \pm 11$ & 0.5 & \\
\hline
\end{tabular}




\subsection{In vitro characterization of the samples}

Figure 2 presents the viability percentages of HGF cells after their exposure to the tested samples (PLGA and PU vs. control).

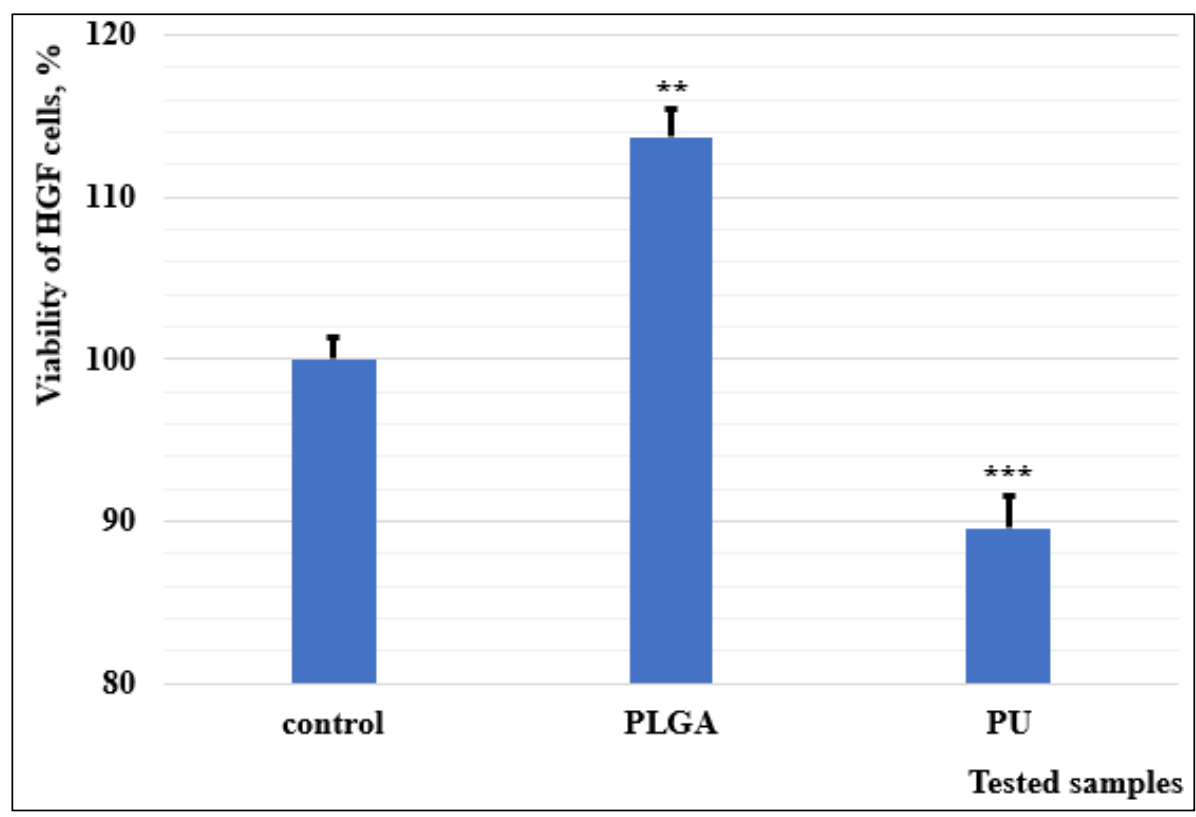

Figure 2. Viability of HGF cells - at $24 \mathrm{~h}$ post-treatment with the PLGA and PU samples by means of MTT assay. Results were expressed as percentage of viable cells (\%) compared to Control (untreated cells). The data represent the average values \pm SE. One-way ANOVA followed by Bonferroni multiple comparisons test were applied for comparison between groups.

$$
(* * \text { for } \mathrm{p}<0.01, * * * \text { for } \mathrm{p}<0.001)
$$

It was observed that the cell viability percentage of HGF cells that were treated with PLGA sample was almost $115 \%$, indicating that the sample elicited a proliferative effect. This effect could have been produced by an interaction of its acidic groups with the MTT reagent, and thus it can be considered a false positive result; similar interactions were identified in other in vitro studies [14-16]. HGF cells viability after treatment with PU sample was almost $90 \%$ and this value is specific to a non-cytotoxic sample. However, due to the limitations of the MTT assay, the LDH technique was applied in order to evaluate a potential cytotoxic effect of the samples. The cytotoxic effect was determined at $24 \mathrm{~h}$ and $48 \mathrm{~h}$ post-treatment with the samples.

The evaluation of lactate dehydrogenase (LDH) revealed similar results; PLGA sample induced a very low cytotoxicity, almost comparable with the control, while the percentages at 24- and 48-hours post-treatment were increased in the case of PU sample. As it was expected, by increasing the stimulation period, the cytotoxic effect also augmented, hence the cytotoxic percentage was $6.71 \%$ after the treatment with PLGA sample at $24 \mathrm{~h}$ and $7.79 \%$ at $48 \mathrm{~h}$; the same evolution was observed in the case of PU sample (Figure 3). 


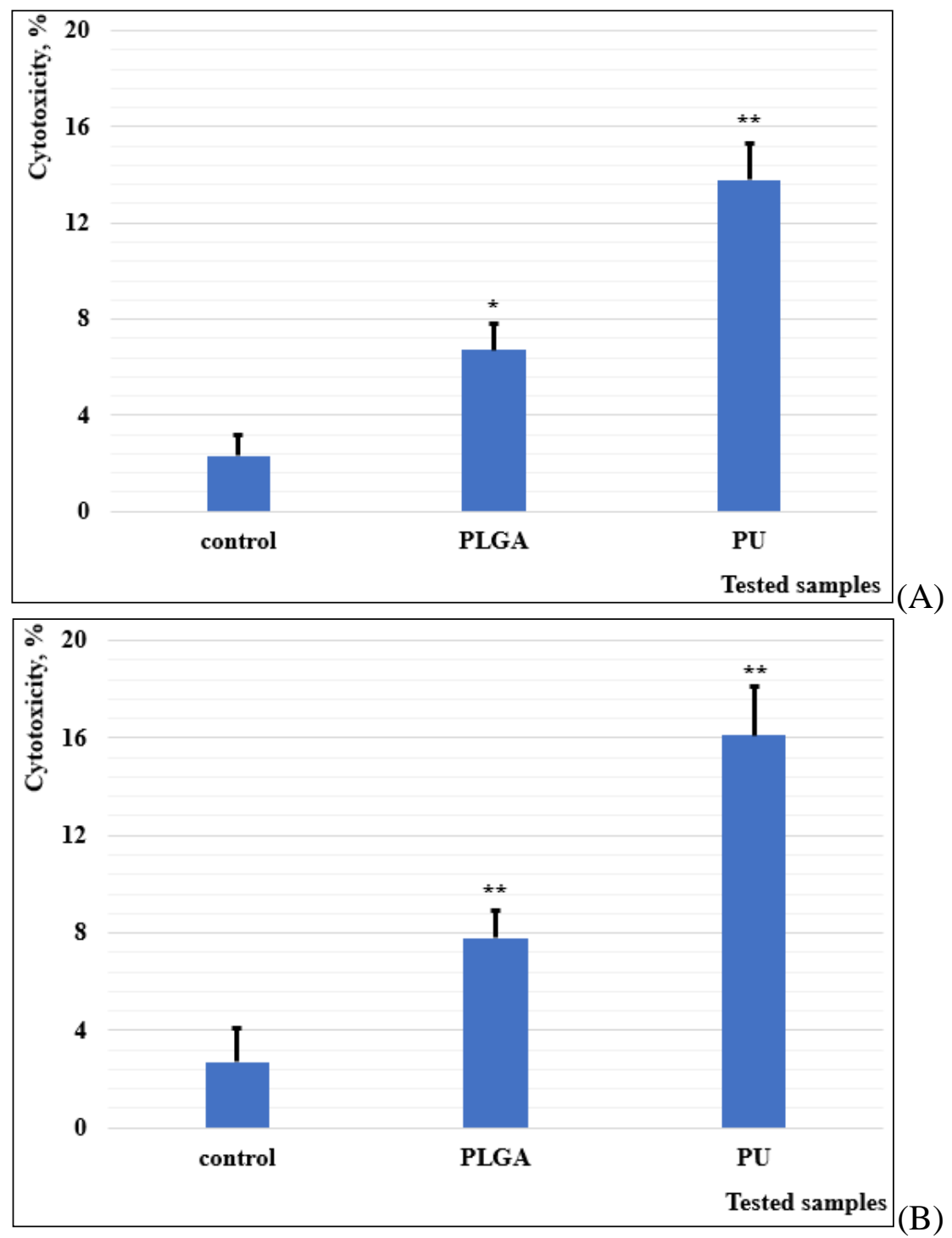

Figure 3. The cytotoxicity analysis of PLGA and PU samples on HGF - human gingival fibroblasts at (A) $24 \mathrm{~h}$ and (B) $48 \mathrm{~h}$ post-treatment by means of LDH assay. Results were expressed as percentage of cytotoxicity (\%) compared to Control (untreated cells). The data represent the average values \pm SE. One-way ANOVA followed by Bonferroni multiple comparisons test were applied $(*$ for $\mathrm{p}<0.05, * *$ for $\mathrm{p}<0.01$ )

The biocompatibility is an essential parameter of the new polymeric composites in regard to their clinical use [8]. Polyurethanes are biocompatible materials that have a long history, more than a half of a century, in different medical applications [9]. However, the present study reveals that PLGA microparticles are even better than PU.

In order to evaluate the biocompatibility of dental materials many in vitro oral models are used as they have different advantages when compared to in vivo experiments; they consist in performance under well-controlled parameters, ease of reproducibility and low costs [17]; nowadays, the in vitro studies performed in specific experimental conditions represent the most proper determination of potential cytotoxic and mutagenic properties of a new synthesized material [18-22].

Given the fact that gingival fibroblasts are directly exposed to the orthodontic implants in normal physiological conditions, the HGF cells represent a good option for evaluating the effect of dental materials. The present results indicated that PLGA sample may be considered as a biocompatible material used in different orthodontic treatments, as they did not decrease HGF cells viability and also had a lower cytotoxic effect than the PU sample. Malkoc S et al. [23] have used the same procedures to 
evaluate mini dental implants. They indicated that the implants acquired from titanium alloy and from stainless steel did not showed a cytotoxic effect on gingival fibroblasts [23].

Dental materials come in contact with tissues and cells and frequently cause damages. They can have a significant allergic, toxic or carcinogenic effect. The physico-chemical qualities and biocompatibility of dental materials such as composites, are necessary conditions in their use in the oral cavity [24-26]. Polymethyl methacrylate (PMMA) $\left[-\left\{\mathrm{CH}_{2}-\mathrm{C}\left(\mathrm{CH}_{3}\right)-\mathrm{CO}-\mathrm{OCH}_{3}\right\}-\right]$ was the most popular material used in dentistry since introduction in 1937 [27, 28]. The properties of composites are influenced by type and extent of filler and inorganic silane and correct distribution of nanoparticles in the organic phase. In vitro studies are necessary to evaluate the biocompatibility of all dental materials [29-31].

\section{Conclusions}

This paper describes the obtaining and a preliminary characterization of two types of polymeric microparticles based on PLGA or PU with a possible application as biomaterials in dentistry. The experimental results reveal the non-cytotoxic potential of the microparticles with a mean size between 160 and $200 \mathrm{~nm}$; the toxicity evaluations, based on ISO standards (MTT and LDH assays on the primary human gingival fibroblasts), show that the synthesized products did not manifest important inhibitory potential on the viability of HGF cells; all objectives of this study have been accomplished and both samples can be further tested in different specific clinical trials.

Although the biomechanical properties of polymeric materials are dictated by their bulk properties, their interactions with tissues are governed by their surface properties, which can be easily adapted to specific requirements.

\section{References}

1. WILLIAMS, D.F., On the mechanisms of biocompatibility, Biomaterials 29(20), 2008, 2941-2953. https://doi.org/10.1016/j.biomaterials.2008.04.023.

2. WILLIAMS, D.F., On the nature of biomaterials, Biomaterials 30(30), 2009, 5897-5909. https://doi.org/10.1016/j.biomaterials.2009.07.027.

3. CHEN, F.M., LIU, X., Advancing biomaterials of human origin for tissue engineering, Prog. Polym. Sci. 53, 2016, 86-168. https://doi.org/10.1016/j.progpolymsci.2015.02.004.

4. SAINI, M., SINGH, Y., ARORA, P., ARORA, V., JAIN, K., Implant biomaterials: A comprehensive review, World J. Clin. Cases 3(1), 2015, 52-57. https://doi.org/10.12998/wjcc.v3.i1.52.

5. MAITZ, M.F., Applications of synthetic polymers in clinical medicine, Biosurf Biotribol, 1, 2015, pp. 161-176

6. SAH, H., Microencapsulation techniques using ethyl acetate as a dispersed solvent: effects of its extraction rate on the characteristics of PLGA microspheres. J Control Release, 47(3), 1997, 233-245.

7. BORCAN, L.C., DUDAS, Z., LEN, A., FUZI, J., BORCAN, F., TOMESCU, M.C., Synthesis and characterization of a polyurethane carrier used for a prolonged transmembrane transfer of a chili pepper extract, Int. J. Nanomed. 13, 2018, 7155-7166. https://doi.org/10.2147/IJN.S181667.

8. CHEN, Z., PATWARI, M., LIU, D., Cytotoxicity of orthodontic temporary anchorage devices on human periodontal ligament fibroblasts in vitro, Clin. Exp. Dent. Res. 5(6), 2019, 648-654.

https://doi.org/10.1002/cre2.230.

9. ISO 10993-5:2009. Biological evaluation of medical devices - Part 5: Tests for in vitro cytotoxicity. ISO catalogue, edition 3.

10. POPOVICI, R.A., VADUVA, D., PINZARU, I., DEHELEAN, C.A., FARCAS, C.G., CORICOVAC, D., DANCIU, C., POPESCU, I., ALEXA, E., LAZUREANU, V., STANCA, H.T., A Comparative Study On The Biological Activity Of Essential Oil And Total Hydro-Alcoholic Extract Of Satureja Hortensis L, Exp. Ther. Med. 18, 2019, 932-942. 
11. DANCIU, C., MUNTEAN, D., ALEXA, E., FARCAS, C., OPREAN, C., ZUPKO, I., BOR, A., MINDA, D., PROKS, M., BUDA, V., HANCIANU, M., CIOANCA, O., SOICA, C., POPESCU, S., DEHELEAN, C.A., Phytochemical Characterization and Evaluation of the Antimicrobial, Antiproliferative and Pro- Apoptotic Potential of Ephedra alata Decne. Hydroalcoholic Extract against the MCF-7 Breast Cancer Cell Line, Molecules 24(1), 2018, 13.

http://doi.org/10.3390/molecules24010013.

12. BALIGA, S., MUGLIKAR, S., KALE, R., Salivary pH: A diagnostic biomarker, J. Indian Soc. Periodontol. 17(4), 2013, 461-465. https://doi.org/10.4103/0972-124X.118317.

13. GALlardO, V., MORALES, M.E., RUIZ, M.A., DELGADO, A.V., An experimental investigation of the stability of ethylcellulose latex: correlation between zeta potential and sedimentation, Eur. J. Pharm. Sci. 26(2), 2005, 170-175. https://doi.org/10.1016/j.ejps.2005.05.008.

14. HALKAI, K.R., MUDDA, J.A., SHIVANNA, V., PATIL, V., RATHOD, V., HALKAI, R., Cytotoxicity evaluation of fungal-derived silver nanoparticles on human gingival fibroblast cell line: An in vitro study, J. Conserv. Dent. 22, 2019, 160-163. https://doi.org/10.4103/JCD.JCD_518_18.

15. VAHABI, S., YADEGARY, Z., KARAMSHAHI, M., Evaluating the adhesion of human gingival fibroblasts and MG-63 osteoblast-like cells to activated PRP-coated membranes, Cell Tissue Bank 20, 2019, 339-349. https://doi.org/10.1007/s10561-019-09772-9.

16. PANDOLEON, P., BAKOPOULOU, A., PAPADOPOULOU, L., KOIDIS, P., Evaluation of the biological behaviour of various dental implant abutment materials on attachment and viability of human gingival fibroblasts. Dent. Mater. 35, 2019, 1053-1063. https://doi.org/10.1016/j.dental.2019.04.010.

17. TOY, E., MALKOC, S., COREKCI, B., BOZKURT, B.S., HAKKI, S.S., Real-time cell analysis of the cytotoxicity of orthodontic brackets on gingival fibroblasts, J. Appl. Biomater. Funct. Mater. 12, 2014, 248-255. https://doi.org/10.5301/JABFM.5000165.

18. GALEOTTI, A., UOMO, R., SPAGNUOLO, G., PADUANO, S., CIMINO, R., VALlETTA, R., D'ANTO, V., Effect of $\mathrm{pH}$ on in vitro biocompatibility of orthodontic miniscrew implants, Prog. Orthod. 14, 2013, 15. https://doi.org/10.1186/2196-1042-14-15.

19. PILLAI, A.R., GANGADHARAN, A., GANGADHARAN, J., KUMAR, N.V., Cytotoxic effects of the nickel release from the stainless steel brackets: An in vitro study. J. Pharm. Bioall. Sci. 5, 2013, S14. https://doi.org/10.4103/0975-7406.113279.

20. MARTIN-CAMEAN, A., JOS, A., PUERTO, M., CALlEJA, A., IGlESIAS-LiNARES, A., SOLANO, E., CAMEAN, A.M., In vivo determination of Aluminum, Cobalt, Chromium, Copper, Nickel, Titanium and Vanadium in oral mucosa cells from orthodontic patients with mini-implants by Inductively coupled plasma-mass spectrometry (ICP-MS). J. Trace Elem. Med. Biol. 32, 2015, 13-20. https://doi.org/10.1016/j.jtemb.2015.05.001.

21. VLAD, C.S., DUMITRASCU, V., VLAD, D.C., POPESCU, R., CIMPORESCU, A., FLANGEA, C., CHEVERESAN, A., SIPOS, S., BARAC, S., MALITA, I., Effects of Materials Based on Acrylic Resines on Inflammatory Markers IL-8 and TGF $\beta 1$ in Gingival Crevicular Fluid, Mater. Plast. 55(1), 2018, 111-114.

22. VLAD, D.C., DUMITRASCU, V., POPESCU, R., CIMPORESCU, A., VLAD, C.S., FLANGEA, C., GRECU, D.S., VAGVOlGYI, C., PAPP, T., HORHAT, F., Gas Chromatography-mass Spectrometry Evidences for New Chemical Insights of Momordica charantia, Rev. Chim. (Bucharest) 66(11), 2015, 1914-1920.

23. MALKOC, S., OZTURK, F., COREKCI, B., BOZKURT, B.S., HAKKI, S.S., Real-time cell analysis of the cytotoxicity of orthodontic mini-implants on human gingival fibroblasts and mouse osteoblasts. Am. J. Orthod. Dentofacial Orthop. 141, 2012, 419-426.

https://doi.org/10.1016/j.ajodo.2011.12.009.

24. OLARIU, I., RADU, R., OLARIU, T., SERAFIM, A.C., POPOVICI, R.A., FLORESCU, S., NICA, C., TODOR, L., TIGMEANU, C.V., An Analysis of Dental Implants Survival and Success, Rev. Chim., 69(9), 2018, 2465-2466. 
25. POPOVICI, R.A., TODOR, L., BALEAN, O., MOTOC, O., PODARIU, A.C., Assessment of the Effects of Several Products of Dental Use After Topical Administration to Different Mice Strain, Rev. Chim., 68(2), 2017, 424-426.

26. EARAR, K., PORUMB, A., MATEI, R., CAVALU, S., POPOVICI, R.A., FOCSANEANU, S., DAWOD, N., SACELEANU, A., TODOR, L., The Glass Ionomer Cement Reinforced with Silver Premise in Choosing the Teeth Proposed for Orthodontic Purpose Extraction, Rev. Chim., 70(1), 2019, 324-326.

27. CIAVOI, G., BECHIR, A., TIG I., DALAI, C., MANU, R., Aspects Regarding the use of Three Types of Polymers as Denture Base Materials, Mater. Plast., 52(2), 2016, 247-251

28. CIAVOI, G., BECHIR, A., BECHIR, E.S., MOLA, F.C., PRIBAC, V., SAPTE, E., DASCALU, I.T., Long Term Trial of Two Dental Resins Used in the Manufacture of the Aesthetic Component of Fixed Restorations, Mater. Plast., 54(2), 2017, 265-268.

29. ALMASI, A., PORUMB, A., PODARIU, A.C., TODOR, L., TOFAN, S.A., POPOVICI, R.A., The Effects of Nanofillers on Composite Materials Mechanical Properties, Rev. Chim., 68(1), 2017, 192-199. 30. PORUMB, A., ALMASI, A., TODOR, L., RATIU, C.A., CIAVOI, G., TODOR, P.C., TODOR, S.A., MATEI, M.N., ROMANEC, C., MATEI, R.I., In vitro Study of the Structure and Adhesive Interface in Direct Restorations with Experimental Nanocomposite Materials and Adhesive Systems, Mater. Plast., 55(4), 2018, 620-625.

31. ALMASI, A., TODOR, L., RATIU, C.A., POPOVICI, R.A., TIGMEANU, C.V., TOFAN, S.A., PORUMB, A., In Vitro Study of the Structure and Adhesive Interface in Direct Restorations with Commercial Nanocomposite Materials, Mater. Plast., 56(1), 2019, 277-281.

Manuscript received: 31.07 .2020 